\title{
Cannes 2004 Report
}

\author{
By Ron Holloway
}

Fall 2004 Issue of KINEMA

\section{THE "NEW" 57eme FESTIVAL DE CANNES 2004}

FOR a quarter century the Cannes film festival has been associated, for better or for worse, with one name Gilles Jacob. As the délégué général of the Festival International du Film for all of 23 years (since 1978), he selected the films, set its pace, and stood at the top of the stairs to welcome producers, directors, and stars to their premiere screenings in the Palais. Pierre Viot, the former festival president and Gilles's right-hand man, took care of the diplomatic honneurs, while Christine Aimé ran the Service de presse like a Swiss watch.

That's all in the past. Cannes, the kingpin of all international film festivals, now has a new name, a new team, a new vision.

First of all, the name. When guests arrived at this year's event - the $57^{\text {th }}$ - they saw the emblem "Festival de Cannes" emblazoned on the facade of the Palais des Festivals, displayed prominently on posters, and decorating the front cover of the catalogue. For some, the change in the name was hardly noticeable because, for nearly a decade now, the official email address has read "festival-cannes.fr." "We simply took out the 'hyphen'," mused Jacob. "Besides, since everybody refers to us as 'Cannes,' the adjustment went smoothly."

As for the team, the trio - Gilles Jacob, President du Festival, Véronique Cayla, directrice générale, and Thierry Frémaux, délégué artistique - was officially introduced to cineastes and festivaliers two years ago on a full page in the $55^{\text {th }}$ anniversary issue of "Cannes Memories," the official festival album. Immediately thereafter, the voice of the festival was the team, no longer an individual.

In 2001, when I stepped into Jacob's office at Cannes for my annual interview midway through the festival, I thought I could trip him up with a question or two about the selection. "This is Thierry Frémaux's festival," he shot back. "People said I would have trouble stepping down from délégué général, but you see: it's been a very smooth transition."

Some news wags claim that the trio is a sham, that Gilles Jacob still is the power behind the throne, that he was reluctant to give up the reins in the first place. Not true, say those who regularly visit the intersanctum of the festival headquarters in Paris. The Festival de Cannes is simply too big to be run by one person.

"We want to make Cannes truly international," confirmed Thierry Frémaux. Meaning: "We allow every country in the world to contribute to the depth and scope of the festival." This year, over 3,500 films were submitted for consideration - an increase of $40 \%$ over 2003. Include the entries in the Cannes Film Market (MIF), and you have a grand total of 1,325 films from 85 countries for the $57^{\text {th }}$ edition of Festival de Cannes!

Last year, when Cannes was hit hard in the press and media as "one of the worst in history," the trio stood firm. "I know some people who come to Cannes without seeing a single film in the competition," responded Thierry Frémaux. "They prefer instead the "rarities": the Restored Prints, the entries in Un certain regard, the Retrospective, and whatever else can be picked out of the Cannes cornucopia."

Looking back over his own quarter-century as artistic head of the festival, Jacob mused that the old adage of "good wine seasons" also applies to "good festival seasons" - meaning that a festival is only as good as the films that are available and submitted. But he also hinted that some festival entries are "late bloomers" - meaning that it sometimes takes a year or two before a discovery at Cannes is actually confirmed on the world film scene as a breakthrough in theme or style.

Take the new Iranian cinema of Abbas Kiarostami and Mohsen Makhmalbaf, for instance. Or Krzysztof Kieślowski's "cinema of moral anxiety." Or the international breakthroughs of Lars von Trier and Emir Kusturica and Quentin Tarantino. They all started or were confirmed at Cannes. 
Look in the "Cannes Memories" scrapbook, and you will find a couple ripe statements about "the worst Cannes festival ever!" Back in 1972, when Maurice Bessy took over from Robert Favre Le Bret to program the $25^{\text {th }}$ anniversary festival, he was hit with the same kind of critical finger-pointing that greeted Thierry Frémaux at the $56^{\text {th }}$ Cannes festival last year. "This is the year of the all-time worst French selection ..." went the refrain led by Robert Chazal, the unofficial chronicler of the Cannes festival.

Maybe so, said other veteran critics who had covered Cannes almost from the beginning. But maybe there were unknown factors that had contributed to the embarrassment of the anniversary flop.

I can remember a conversation around the Variety counter one afternoon in the foyer of the Hotel Carlton. Many of the "muggs" had only praise for Maurice Bessy for "breaking ranks" and exposing the pitfalls of the Favre Le Bret years. As the story went, the Hollywood studios pretty much dictated which American film would be officially entered in the competition at Cannes. Furthermore, since the jury president was given two votes to cast at showdown time, and since Favre Le Bret himself sat in on the final jury deliberations, the doors were left wide open for greasing the palm of all and sundry. "After all, a Cannes kudos might be worth a couple million in European advertising," opined Gene Moskowitz, the Variety mugg in Paris.

This kind of fiddle-faddle was alien to Maurice Bessy. "I could no longer just blindly accept each country's entries," he stated emphatically in the French press. "But demanding that the decision be made by us was a hard battle. Still, it was evident that such freedom of choice would lead to improved quality, a fact that was confirmed at festivals to come at Cannes."

Those words were prophetic in more ways than one. Not only did his "open door" policy lead to a flood of films for new programming sections and the burgeoning film market, but overnight some 30,000 film professionals also descended on the Croisette and rue d'Antibes to party and barter. Then, to counteract and supplement the flourishing Semaine internationale de la critique (International Week of the Critics, founded 1961) and Quinzaine des réalisateurs (Directors Fortnight, founded 1969), he launched Les yeux fertiles (The Creative Eye) in 1975, followed by L'air du temps (Pulse of the Times) and Le passé composé (Documenting the Past) sections in 1977. A year later, Gilles Jacob grouped all three innovations together under a new Cannes rubric: Un certain regard (A Certain Look), now in its $26^{\text {th }}$ year as a kind of delicatessen shop under the festival umbrella.

Some say that Bessy's adamant stance to protect and promote cinematic art at all costs led to his downfall five years later - to say nothing, of course, of his irascible and sometimes fiery temperament. In any case, the contretemps paved the way among the powers-that-be to pick a likeable Express critic to become the next délégué général on the Croisette. And over the years Gilles Jacob has done his utmost to protect the image of the festival by promoting the independence and safeguarding the integrity of his selection committee.

For many years, some French critics thought Jacob had committed a fundamental error by ostracizing the Hollywood studio community. Pressure was also put on him to reschedule the festival to an autumn date, as was the case in année zéro (1-20 September 1939) and the immediate postwar years (until 1951), when the decision was made to settle for dates in the spring. And when in the 1980s the Venice film festival was in danger of sputtering out altogether, due mostly to government bickering over the budget, there was talk again of Cannes usurping the birthright of the Biennale. Luckily, for both sides, nothing came of this idle chatter.

One cannot underestimate Gilles Jacob's determination to resist outside pressure from the Hollywood studios, whose bosses tried on several occasions to tunnel a Trojan Horse into the Cannes compound by way of socalled "package deals." Jacob responded with a Trojan Horse of his own: Tom Luddy of Zoetrope and the Telluride Film Festival, whose close links to the Nouvelle vague Américaine - to wit: such auteur directors as Francis Ford Coppola, Bob Rafelson, Robert Altman, Hal Ashby, Martin Scorsese, Paul Schrader, Jim Jarmusch, the Coen Brothers, among others - were to reap enormous benefits for the festival by motivating independent filmmakers the world over to try their luck in the Cannes sweepstakes. As the late influential German critic Peter Buchna put it, "New German Cinema owed its very existence to Telluride and Cannes."

For years, Cannes kept the names of its selection committee secret. Only scouts were visible on the festival byways: publicist Pierre Rissient, critic Max Tessier, staffer Christian Jeune. But scouting is one thing, selecting another. Ultimately, so everyone said, the decision was made by Gilles Jacob, who seldom left 
Paris and was kept informed with literally thousands of video cassettes and DVDs in his private collection. I can remember just one occasion when Jacob paid an unexpected visit to the United States - it was to receive an award from Agnes Gund, a board director at the Museum of Modern Art. On the other hand, why leave Paris when nearly every hour of the working day you received a visitor or a phone call from a producer, a director, a distributor, a press agent?

Just recently, however, a decision was made to release the names of the Cannes Selection Committee. For what it's worth, here they are: For French Films: Gilles Lyon-Caen, Lucien Logette, and Philippe Piazzo. For Foreign Films: Virginie Apiou, Guy Braucourt, Paul Gransard, and Laurent Jacob. The one name of singular importance on this list is Laurent Jacob, the son of Gilles, who has made a name for himself with compilation documentaries on the Cannes film festival (often in unison with his father).

As for the Foreign Correspondents, these number some able critics and cineastes: Joël Chapron (Central and Eastern Europe), Lorenzo Codelli (Italy), Mamad Haghigat (Iran), Christiane Peitz (Germany), Brice Pedroletti (Asia), Agnès Poirier and Simon Perry (Great Britain), Jose Maria Riba (Spain, Latin America), Ilda Santiago (Brazil), Magda Wassef (Mediterranean countries). According to Christiane Peitz, the German correspondent, she has been relaying background information and recommendations to Thierry Frémaux at regular intervals. Now, after an eleven-year drought, the heavens have opened and a German film has been invited to compete for the Golden Palm: Hans Weingartner's The Edukators, a German-Austrian coproduction.

Ask Thierry Frémaux why one film was selected over another, and he will beg the question - as he did shortly after the press conference for the 2004 Cannes festival. "There are no rules or criteria for making the selection," he confirmed. "As the films are screened, gradually and little by little a few will stand out as imposing productions. Finally, are the films themselves the reason for being selected?" In other words: see the films yourselves - and make up your own mind.

Oddly enough, one question posed to both Thierry Frémaux, the artistic director, and Véronique Cayla, the general director, brought entirely different answers. Ask if Cannes is one festival, or many festivals under one umbrella, Frémaux responded: "In the same way that there are numerous categories of festivals, so too there are several festivals at Cannes. Thus each of us - the journalist, the professional, the amateur, the cinéphile - will approach the festival in a different way."

On a note of amused attrition, he added: "Let's face it - some people are here only to walk up the stairs in evening dress." And he closed on something apparently quite close to his convictions: "By all means, don't miss the new section: the Cinema on the Beach screenings!"

By contrast, Véronique Cayla, takes an entirely different perspective. "Of course, the Festival de Cannes is one, and we do our best to keep it looking that way! This is a festival of diversity and richness, yet linked to a unique identity!"

Cayla also emphasized that Cannes is like "a person growing up - each year, we embrace new experiences." Although she only joined the team three years ago, in 2001, she ticked off all the giant steps taken in the past: The Caméra d'or in 1978, then, ten years later, the Cinéfondation in 1998. The Leçon du cinéma, launched in 1991, with Stephen Frears this year. The Music Master Class, started in 2002, now with composer-pianists Lalo Schifrin and Bruno Fontaine. And for the first time Max Von Sydow conducting an Actors' Master Class.

Asked to list priorities among the maze of her administrative duties, Véronique Cayla cited three main points.

First, European Day on May 18 ${ }^{\text {th }}$. Altogether, 25 Ministers of Culture will discuss about "becoming a filmmaker" with Miloš Forman, Stephen Frears, Jean-Claude Carrière, and young talent. It follows on the heals of a symposium on piracy on May $16^{\text {th }}$, during which heads of major international studios will meet to try to find an appropriate answer on this question.

Second, the new Short Film Corner in the International Village offers an opportunity for young filmmakers to present their works under optimal screening conditions to a new Producers Network of some 400 members.

Third, the Cannes Mix, a showcase for international DJs, accompanies the Cinema on the Beach program 
and augments the already established Musical Promenade along the Croisette. Then, on closing night, when the Palms are handed out, the festival ends with the De-Lovely salute to Cole Porter and a great concert on the beach.

Last, but not least, Gilles Jacob harbors a vision of things to come at Cannes. Together with Véronique Cayla, he paid a visit to the office of Bernard Brochand, the Mayor of Cannes. Five years from now, they want to open a Musée du Festival just beyond the port along the road to La Napoule, not far from the Hotel Sofitel. The cornerstone for this museum of the moving image will be laid in 2007, on the occasion of the $60^{\text {th }}$ anniversary of the Festival de Cannes and the $30^{\text {th }}$ anniversary of the Centre Pompidou in Paris.

For the next five years, Gilles Jacob and his team will have their hands full. For the Musée du Festival will offer to cineastes a videotheque of all the films shot on the Côte d'Azur and everything on film and video about the Cannes film festival since its origin.

"This task will be sheer delight," concluded Gilles Jacob.

\section{An Awesome Cannes Festival}

"The official festival has become gigantic, is certainly unique in the world, and yet manages to find room for all its offspring," penned Jean Roy in L'Humanité about the $57^{\text {th }}$ Festival de Cannes. Another critic compared the festival to a sprawling mosaic in an archaeological dig that reveals more than first meets the eye. Meaning: it's when you fit all the pieces together that you begin to realize that this was one of the finest cinematic showcases in the history of the festival. Yet, particularly for Cannes veterans, this year's innovations puzzled as much as they challenged. Why two documentaries and two animation features contending for Palme d'or honours? In retrospect, one of each would have been enough. Why yet another masterclass? For the first time, a Leçon d'acteur by Max von Sydow was launched to join the recently established Leçon de musique, this year with Lalo Schifrin, and the long established Lȩ̧on de cinéma, conducted this time around by Stephen Frears.

Another question that occupied the press was whether or not the festival's second annual "Europe Day" (May 17), for which invitations were accepted by 25 cultural ministers of the newly constituted European Union, would become a permanent "cultural film summit" on the Riviera. To assure peace on the streets, however, a deal was brokered with the demonstrating intermittents du spectacle (striking arts workers) to prevent a recurrence of what had happened in 2003 at the Avignon theatre festival, while throughout the Cannes festival the CRS (French Riot Police) stood in readiness each night on the backstreets before the Palais des Festivals. Cineastes and film historians wondered aloud if the new "Cinema Classics" section would develop even further in the future as a result of the success this year: a live orchestral accompaniment of Buster Keaton's restored The General (USA, 1926) by the PACA Regional Orchestra, featuring a fetching original score by Japanese composer Joe Hisaishi (film composer for Takeshi Kitano). "I remember the power of Buster Keaton's comic talent," said Hisaishi. "I was surprised to find basic elements of Japanese comic art in his performance." All of which just skims the surface of this awesome festival. As this year proved in magnificent fashion, Cannes is truly the only film festival on the calendar that has the vision and finesse to blend an illustrious past with the luminous present while setting an enlightening course for the future.

\section{Archives and Film History}

For my tastes, one of the major historical moments of the festival was the three-and-a-half-hour screening of Jacques Richard's documentary Le fantôme d'Henri Langlois (Henri Langlois: The Phantom of the Cinematheque, France), a veritable history of cinema as told on and off camera by the legendary founder of the Cinémathèque Française in a give-and-take discourse over the years with friends and critics. It was programmed in the new "Sur, le cinéma" (About Cinema) section, a selection of five documentaries about cinema. In the same section was a perplexing documentary about Sergei Paradjanov, titled I Died in Childhood (Russia) and assembled from newly found material by his nephew Georgi Paradjanov. It focuses primarily on Paradjanov's first and last day of shooting of his last project, Confession, an autobiographical feature film that was interrupted by an emergency operation on a cancerous lung. According to the director, well over 30 films have been made about the legendary- Sarkis Paradjanian (his christened name) since his death in 1990. I Died in Childhood commemorated the $80^{\text {th }}$ anniversary of his birth. 
Another engrossing moment was Gilles Jacob's Épreuves d'artistes (Words in Progress), in which the President of the Festival de Cannes spliced together an entertaining potpourri of press conferences over the years with famous film directors in a kind of "March of Time" on the Riviera. This is the third in Jacob's delightful trilogy about how modern cinema was written at the Cannes film festival, following Histoire(s) de festival (Festival Stories) in 2002, in which he pays tribute to the great masters of cinema, and Les marches, etc. (The Steps, etc.) in 2003, in which he chronicles the ritual on the Cannes steps as a "musical comedy" to the blaring of trumpets and the rhythm of Offenbach. Few know the history of Cannes better than Gilles Jacob, whose presence on the Croisette dates back to 1964, when, forty years ago, he first plied his trade as a visiting journalist for L'Express. Asked about the future, the president du festival underscored in his response the ultimate purpose of his compilation documentaries: "Recently Véronique Cayla (directrice générale) and I paid a visit to the mayor of Cannes. In 2006, if all goes well, we plan to break ground for an archival museum of Cannes film history."

\section{The Signature of Thierry Frémaux}

This was the first time in four years that Thierry Frémaux (délégué artistique) personally selected the films in contention for the Palme d'Or. And since the official program stemmed from his initiative, it goes without saying that the competing films also reflected his own personal tastes. Indeed, Frémaux made every effort to attend the key press conferences, and he was ever-ready for comments and criticism from press and media. As for where his personal input was clearly visible, try Asian cinema, for which the international jury awarded him with a show of largesse. All but two of the six Asian entries in competition - two from Japan, two from South Korea, one each from China and Thailand - were voted prizes by the jury.

Further, none of the three French films in competition went away empty-handed either on awards night. And the all-embracing festival homage honouring Jean-Luc Godard included occasional excerpts before competition screenings from his nouvelle vague classics (A bout de souffle, Le mépris, Les carabiniers, Bande à part, etc.), all leading up to the screening of his new film, Notre musique, with its spotlight on the tragedy at Sarajevo. For the first time in eleven years, a German film was selected for the competition, albeit an Austrian coproduction. And the innovation of allowing press and public an opportunity to review all the competition entries again on the day following the gala awards ceremony also meant that the jury members could defend their favourites in public, if they so desired. In this regard, it should be added, the oft publicized "jury showdown" between American cult director Quentin Tarantino (jury president) and British avant-garde actress Tilda Swinton (jury member) didn't seem to have any effect at all on the jury's final decisions.

\section{Agit-Prop or Political Pamphlet?}

Although Michael Moore's Fahrenheit 9/11 (USA) was the wish candidate of most critics to win the Palme d'Or, still its triumph on the night of the awards gala had both a stunning and jubilant effect on the audience. For not since Jacques-Yves Cousteau and Louis Malle's Le monde du silence (The World of Silence, France), back in 1956, had a documentary entry come this far in the Cannes competition, to say nothing of winning the Grand Prix. Much has been written about the controversial thematic content of Fahrenheit 9/11, with open-ended guesses made as to why Disney had dropped its release contract like a hot potato, only to have it bought back by producer-backer Miramax. And much more will be hyped by the media when the film makes the rounds of major American cities as a tub-thumbing, Bush-bashing, lampooning, all-out assault on the present Republican administration in the run-up to the next presidential election in November. "You have put a huge light on this movie," said Moore upon receiving the Golden Palm. "You will assure that the American people will see this movie." Certainly it wasn't a coincidence that on the very day that the Cannes jury assembled to vote on the award winners, columnist Frank Rich of the New York Times had already penned a scathing anti-Bush review in the Herald Tribune under a rather polemic headline ("Beautiful Minds, Ugly Truths"), a review that may have helped to Moore to win the coveted Palm.

Some European critics classified Fahrenheit 9/11 as an agit-prop film - that is, meant to agitate with political propaganda. Political it is, but agit-prop it is not. Rather, it falls in the grand American tradition of the "political-pamphlet" - harking back to Thomas Paine's 47-page hard-hitting, provocative "Common Sense" pamphlet at the dawn of the American Revolution. Further, Fahrenheit 9/11 is admittedly a work-in-progress. It's been reported that Moore has in his contract a clause that permits him to update the film as events roll down towards election day with more revelations of government chicanery in the Iraq debacle still to come. And one had only to pay a visit to the Cannes market for a screening of Robert Greenwald's documentary 
Uncovered: The War on Iraq (USA), an intellectual indictment of the Bush Administration, to grasp where the ebullient Moore has borrowed some of his high-powered footage. Frank Rich, too, broadly hints that employees at TV stations have handed Moore video material under the table to fatten out his political pamphlet. And Quentin Tarantino, although a confessed admirer of Asian cinema, went far out of way on awards night to whisper in Michael Moore's ear that he was being honoured for a "cinematographic" film rather than just a "political" statement. Be that as it may, the weeks and months ahead should counteract the hybris of such hair-splitting.

\section{Winners and Losers}

Save for a few exceptionally stimulating scenes, the Asian entries were generally a disappointment. Awarded the runner-up Grand Prix, Park Chan-wook's Old Boy (South Korea), the second in his announced trilogy on transgression and revenge, paled in comparison to his Beksoneum naegut (Sympathy for Mr. Vengeance, 2002). In this weird tale of a man mysteriously imprisoned for 15 years for an offence he neither remembers nor comprehends, when more light is shed on the nature of the transgression, Park shifts in his jumbled narrative between slapstick and violence over a wearisome two-hour stretch. Midway through the ordeal, when the protagonist Oh Dae-su (Choi Min-sik) is compelled to eat a live octopus, even committed Asian devotees rose to leave their seats at the press screening. At least in Park's earlier Sympathy for Mr. Vengeance, a compelling psycho-drama exploring the theme of vengeance by people caught in a web of fateful events, the scenes of death and violence were handled with an discerning eye for the human condition.

Surprisingly, Wong Kar-wai's 2046 (China-France) went away empty-handed. The long-awaited sequel to Wong's heralded In the Mood for Love (2000), the print arrived at Cannes at the last minute, thus necessitating a switch in the program with Olivier Assayas's Clean (France-Canada-UK). We find ourselves back again with Tony Leung in the same hotel room - "Room Nr. 2046 - this time as a writer working on a science-fiction novel set in the future (2046?), but really dealing with the past and thus blurring the lines with the present. A tale pegged this time around a trio of female apparitions - Gong Li, Zhang Ziyi, Maggie Cheung - one misses the chemistry between Tony Leung and Maggie Cheung that made In the Mood for Love a cult classic. When Maggie Cheung was awarded Best Actress for her performance in Assayas's Clean as a drug-addicted pop-artist, a fallen sinner who then gets a grip on her destroyed life to win back her son, this was the moment that certified Cheung, a multi-talent with languages and cultures deftly blended into a charismatic personality. She gives such a captivating performance in Clean that she will surely now be in heavy demand on the international production scene.

\section{Cult Directors}

By contrast, Hong Sang-soo's Le femme est l'avenir de l'homme (Woman Is the Future of Man, South Korea-France), a MK2-financed production shot in Seoul by a South Korean cult director, ambles casually along a trail of memories about a lost love shared by friends for the same woman without ever reaching a point of narrative departure or even bothering to settle upon a notion of the psychological meaning of sex. Unless I am mistaken, Woman Is the Future of Man simply picks up where Hong left off in Oh! Soo-jung (Virgin Stripped Bare by Her Bachelors, 2000), an entry in the Un Certain Regard section at the 2000 Cannes festival. A modern tale of love and desire in a troika context, Oh! Soo-Jung also featured two young men, art students at the same college, who are attracted to the same girl. Since the woman is a virgin, and one man is more experienced than the other, the relationships among the trio become more complex as passions force changes in character and attitude - all of which is hinted in the film's English title, Virgin Stripped Bare by Her Bachelors. This time, in Woman Is the Future of Man, an arts teacher meets his old friend, a penniless filmmaker who has just returned home from a sojourn in the United States, and their conversation seldom shifts from memories of an unrequited love.

Similarly, another Asian cult filmmaker appears to have lost his directorial footing. For although Apichatpong Weerasethakul's Sud Pralad (Tropical Malady, Thailand-Italy-Germany-France), awarded a share of the Jury Prize, marked the first time that a Thai film was invited to compete at Cannes, the story's rambling transition from a gay romance to a mythical, magical, transcendental hunting myth begs the comprehension of a western audience no matter how meaningful for the home crowd. Far more impressive was Weerasethakul's prior film, Sud Senaeha (Blissfully Yours, 2002), a Thai-French coproduction invited to the Un Certain Regard section at the 2002 Cannes festival. In Blissfully Yours, a story inspired by the arrest of illegal Burmese immigrant women in Bangkok, Weerasethakul explored the idea of moments of happiness surviving in an oppressive 
environment, of pleasure accompanied by suffering, of the coexistence of lightness and darkness. In Tropical Malady he doesn't take this theme much further by introducing in the second half of the film a shaman that changes shapes in a magical forest from a human guise to a soul-stealing predator. Or something along those lines, as far as I could make out.

\section{Asia Goes Digital}

According to a declaration released during the Cannes festival by the South Korean Ministry of Culture, the Korean government will pledge $\$ 33$ million from 2005 to 2007 for the research and development of digital cinema. The funds will be used not only to improve digital production technology, but also to support the installation of digital projectors in cinemas and to convert films in the Korean Film Archive into digital format. One Asian critic rightly pegged Park Chan-wook's Old Boy, a hit at the home box office, as a "sine qua non" of digital technology. As for the two Japanese entries in the competition, Kore-Eda Hirokazu's Daremo Shiranai (Nobody Knows) and Oshii Mamoru's Innocence (aka Ghost in the Shell 2: Innocence), taken together, they confirmed in no uncertain terms that digital shooting is fast becoming the norm in Japan. Nobody Knows, a heart-breaking fiction-documentary about a mother who abandons her four children (all from different fathers) for her next misguided love affair, merited a Best Actor award for 12-year-old Yagira Yuya, who plays the oldest of the four siblings. Based on a true story, the film is told with a light hand and attention to details. Since only the boy is allowed to leave the apartment, because the rest were smuggled into their new abode inside of suitcases, he must find ways as the surrogate parent to provide the siblings under his care with food and amusement as the days of isolation pass from days into weeks, then into months and the changing seasons. A poignant tale, it deserved recognition by the jury. Hardly a stranger to Cannes, Kore-Eda Hirokazu, originally a documentary filmmaker, made his mark back in 2001 with Distance, an impressive debut feature about four friends journeying to an isolated lake on the anniversary of a cult massacre initiated by an apocalyptic religious sect. He has a way of drawing an audience close to vulnerable individuals as they wrestle with the tragic consequences of misguided life-styles.

By contrast, the digital animation in Oshii Mamoru's Innocence appears to have been designed by computers for presentation strictly on computers. Once again, we are thrust into a claustrophobic future of mechanized human robots and other hyper-realistic creatures of a spiritual domain that only resemble humanity. In the middle of all this chaotic confusion a detective from the anti-terrorist commission investigates the case of a female robot on a killing spree. By contrast, the only puzzle to be unravelled in Shrek 2 (USA), the other animation feature in the competition, was to discover how many favourite movie citations the Dreamworks team of Andrew Adamson, Kelly Asbury, and Conrad Vernon integrated into the new adventures of Shrek and Princess Fiona with their Donkey sidekick and the ogre-killer Puss-in-Boots in the Kingdom of Far, Far Away. There are so many jokes and jests, gags and gibes, well, just plain word-play fun aimed at over 30 Hollywood movies and popular TV series - from Frankenstein and The Wizard of Oz to Rawhide and Mission Impossible that one sitting is hardly enough. Arguably, Shrek 2 will go down in the books as the most entertaining intellectual cartoon feature ever made!

\section{French Cinema Rebounds}

After the highly publicized entry pratfalls at last year's Cannes festival, French cinema rebounded with awards for all three of its competition entries. Maggie Cheung's performance in Olivier Assayas's Clean raised a drug-scene melodrama to a tour-de-force exploration of personal guilt and moral expiation. Agnès Jaoui, an actress turned writer-director, whose previous feature Le goût des autres (The Taste of Others, 1999) had been showered with Césars, topped that award-winning triumph with yet another remarkable feat of cinematic artistry: Comme une image (Look At Me). A film with interwoven story lines, multiple dramatic layers, and delightful psychological spinoffs, the focus is on two artistic families, both headed by writers and supported by musical talents. Look At $M e$, a splendid audience hit, also satisfied the critics with its clever plot twists and ensemble performances. Agnès Jaoui and Jean-Pierre Bacri, co-screenwriters and key protagonists in the film (as well as being a married couple in real life), were awarded Best Screenplay, although many felt Jaoui as writer-director-actress deserved much more.

Instead, Tony Gatlif was awarded Best Director for Exils (Exiles), a road movie about a young Arab couple, Zano (Romain Duris) and Naima (Lubna Azabal), "children of the diaspora" honed in the ways of western culture, who on an impulse leave Paris to hitchhike by foot, train, and ship back to their family roots in Algiers. The journey takes us through the south of France, on an excursion through Andalucia, then 
unexpectedly on a detour to Morocco (Zano got on the wrong boat), and finally across the desert rim to Algeria. Zano, raised as an orphan, can taken as the alter ego of the director, Gatlif, who born in 1948 in Algiers, emigrated to France in the 1960s, and hasn't returned to the land of his birth for the past four decades. The more interesting figure in the story, however, is Naima, who doesn't speak Arabic and is often questioned by people on the way - mostly illegal emigrants from North Africa going in the opposite direction - whether or not she is a Muslim girl, for her dress and manners contradict custom. "I feel like a stranger everywhere," says Naima on one occasion. Best known for his musical savoir-faire, Gatlif adds this component to the overall structure of Exiles: techno-beats blend with flamenco rhythms and culminate in a sufi dance-trance that powers to a peak ending.

\section{German or Austrian?}

Make a note of Hans Weingartner's Die fetten Jahre sind vorbei (The Edukators, Germany-Austria). At its premiere in the Palais des Festivals, it was greeted with a standing ovation, particularly for the fine acting performances in this diverting story of three young would-be revolutionaries who meet their match in an old-timer who had cut his own revolutionary teeth on the 1968 student revolt. A word of praise should also be extended to the skilled photo-cinematography team of Matthias Schellenberg and Daniela Knapp, whose expertise enabled a blowup to $35 \mathrm{~mm}$ from digital DVC Pro 50.

Originally titled Jan Jule Peter - after the names of the three rebellious youths: Jan (Daniel Brühl, who teamed for the second time with Weingartner), Peter (Stipe Erceg, for whom the role was especially written), and Jule (Julia Jentsch, a proven stage actress) - The Edukators is about disillusioned youth who share a passion for changing the world. As so-called "Edukators" they resort to non-violent means to warn the affluent that their "fat years are over" (the direct translation of the German title). In general, their ploys are rather harmless. They break into posh Berlin villas when their owners are away and scatter the owner's prestigious status symbols - stereo equipment in the icebox, pseudo-art objects in the bathtub, chic furniture in the swimming pool - without otherwise resorting to punishable criminal tactics. And they top the burglary off with a graffiti maxim smeared on the wall: "Your days of plenty are numbered!"

Complications mount when their next "let's-mess-things-up" operation runs amuck because the businessman returns home unexpectedly. What was never intended to be a kidnapping forces the three young idealists to reevaluate their lives. The "suburban capitalist," Hardenberg (Burghart Klaussner, in an excellent character role), can relate to their actions in ways they hardly expect, for he had spent much of his own youth as an "angry revolutionary." So the film changes course midstream - from an urban parable with socio-political sting to a tragicomedy spiced with witty dialogue. The twist comes when all four find themselves in an isolated Alpine hut, and the trio don't know exactly what to do next. They awake one morning to find breakfast being made by their captive. A game of one-upmanship ensues, with the old "68er" holding the better cards because he has been through all of this before. The "edukators" undergo a crash course in revolutionary politics.

\section{Latin American Cinema}

For some reason, Latin American cinema was overlooked by the international jury. Awarded the Ecumenical Prize and the Prix Vulcain (technical award to cameraman Eric Gautier), Walter Salles's Diarios de motocicleta (The Motorcycle Diaries, Brazil-Argentina-USA) was an odds-on favourite for a top award by the critics, if for no other reason than that The Motorcycle Diaries scores as a compassionate, although somewhat romanticized version of how in 1952 Ernesto "Che" Guevara (Gael Garcia Bernal) became a revolutionary. As the story goes, he was a young doctor from an average middle-class Argentinean family when he first encountered the pain and suffering of the downtrodden poor while on a motorcycle trip on a 1939 vintage Norton 500 (nicknamed "La Poderosa") across South America with his friend Alberto Granada, upon whose diaries the story is also based and whose presence at Cannes was a festival highlight. Mexican actor Gael Garcia Bernal gives a remarkable performance as the young Che Guevara. A rising screen star, he also appeared in drag in Pedro Almodóvar's La mala educación (Bad Education), the Spanish cult director's morbid account of sexual abuse in a Catholic boarding school and an over-the-top apologia for his own homosexuality. Although Almodóvar claimed at Cannes at the press conference for Bad Education, which opened the festival out-of-competition, that the film is not autobiographical, he obviously revelled in the publicity. "I love you all," he saluted the press corps. 
Argentinean cinema is currently riding a wave of festival acceptance, thanks to a phalanx of talented newcomers: Lucrecia Martel (The Swamp), Carlos Sorin (Minimal Stories) Santiago Loza (Strange), Lisandro Alonso (Liberty), Israel Adrian Caetano (Bolivia), Celina Murga (Ana and the Others), Alejandro Chomski (Today and Tomorrow), and Martin Rejtman (The Magic Gloves). Actually, Lucrecia Martel's The Swamp (2001), awarded Best Debut Film at the 2001 Berlinale, is a metaphorical misnomer, for its Spanish title, La Ciénega, refers to the name of a town in northwest Argentina, where the film was set. Martel returned to the same town to shoot La niña santa (The Holy Girl), another poignant psychological study, in a rundown spa hotel where a convention of medical doctors takes place. Helena (Mercedes Moran) and Amalia (Maria Alché), mother and daughter, are both intrigued by the same visiting medic, the twist being that Amalia equates Catholic spirituality with adolescent sexuality, thus misunderstanding a physical sexual encounter with the older man. When she sets out to reconcile her faith with her concupiscence by initiating a provocative teasing game, The Holy Girl has its comic moments and ends on a tragic note.

Exiled Chilean director Patricio Guzman's documentary portrait of Salvador Allende (Chile-France-BelgiumGermany-Spain) marks the director's return to the scenes he shot on the spot during the 1973 coup that saw the assassination (some say he chose suicide over exile) of a freely elected socialist president and the beginning of a harsh 17-year dictatorship under General Pinochet. After thirty years of chronicling The Battle of Chile in three documentaries between 1973 and 1979, followed by Chile, La Memoria Obstinada (Chile, the Obstinate Memory) in 1997, Salvador Allende appears to be the final filmic segment in his historical mosaic. Shot in Santiago over a six-week period, the film unearths new information on the life and death of a charismatic politician who admired Castro, Che Guevara, and Ho Chi Minh.

\section{The Oddities}

When I viewed the botched version of The Ladykillers (USA) by the Coen Brothers, I sighed with some relief that the 1955 Ealing comedy directed by Alexander Mackendrick is still the classic that it was. And when I read in a news clipping that the filmmaking pair had originally written the script for Barry Sonnenfeld to direct, who then turned the tables on the Coens by deciding to produce the film instead, that heightened the irony of the situation even more. Instead of merry old London, the setting is now the Deep South. Instead of a sweet Mrs. Wilberforce played by Kate Johnson, Irma P. Hall steals the show from Tom Hanks (more of a John Carradine than an Alec Guinness) as the gospel-lady Mrs. Mumson - for which performance she was awarded the Jury Prize.

Jonathan Nossiter documentary Mondovino (USA-France), running in competition, was the real puzzle of the festival. Running at an elongated 160 minutes, the focus - rather, a shaky hand-held camera - is mostly on the crass crusading world of wine growers and sellers, although it was stated in an interview that the film is but a portion of a 10-hour TV series. To Nossiter's credit, a pair of wine experts, France's Michel Rolland and America's Robert Parker, are spotlighted as pompous purveyors of standardization in the huge wineries around the world (thus the title). And one can delight in statements by native gentry, who grow and drink their own wine without bothering to market it, that, after all, a good bottle of wine tastes pretty much the same as any other.

Paolo Sorrentino's Le consequenze dell'amore (The Consequences of Love, Italy) is the second feature by a Neapolitan director to keep an eye on. Set in an Italian-Swiss lakeside hotel, The Consequences of Love explores the rationale of Titta Do Girolama (Toni Servillo), a middle-aged Italian who is a permanent resident and spends most of his time smoking cigarettes and watching the hotel guests, some down on their luck, others oddball figures like himself. Once a week, Titta dutifully takes his dose of heroin. Every now and then, he visits the local bank to deliver a suitcase containing huge sums of money, waiting to have it counted by hand. When a heavily guarded mafia boss arrives, they meet in the hotel's conference room. Into Titta's detached, almost claustrophobic world comes Sofia (Olivia Magnani), a beautiful barmaid whose very presence augurs mystery and suspense. A moody, stylish film, its Pirandello aspects merited applause from the arthouse critics.

Emir Kusturica, past winner of two Golden Palms (for When Father Was Away on Business in 1985 and Underground in 1995), returned to Cannes with Život je čudo (Life Is a Miracle, Serbia-Montenegro-France). To a certain extent, Life Is a Miracle is the reverse comédie humaine side of the Balkan War that he had earlier depicted in Underground as grotesque black comedy. Motifs are borrowed too from his comedy hits, 
particularly the wild-and-woolly slapstick antics seen in Time of the Gypsies (Cannes, 1988) and White Cat, Black Cat (Venice, 1998). The soccer game that ends in complete chaos runs at a madcap pace, as does the village celebration to build a railroad in northern Bosnia-Herzegovina to link the two. Beneath all this earthy fun runs a Romeo and Juliet romance between a Serb engineer and a Bosnian girl, who has been taken prisoner in order to arrange a trade for the engineer's captured son in the war. All things considered, a rather preposterous scenario. At first glance, Emir Kusturica in Life Is a Miracle appears to be contemplating a return to his birthplace, to Sarajevo, the city that experienced the longest siege and blockade in the $20^{\text {th }}$ century (1992-96). But when I asked Emir about the possibility, he responded with an emphatic: "No Never!"

\section{The Sidebars}

The Un Certain Regard section closed on a high note: the last chapter in veteran Egyptian director Youssef Chahine's autobiographical "Alexandria film portfolio." After Alexandria Why? (Silver Bear, Berlin 1979), Memory (1982), Adieu Bonaparte (Cannes Competition 1984), and Alexandria Again and Again (Directors Fortnight, Cannes 1990), now comes Alexandria ... New York, with Mahmoud Hermeida in the alter ego role of Yehia. Put all these films together, as some festival will surely do in the near future, and you have also have a reflective account of 50 years in the cinema.

For the second year in a row, the International Week of the Critics (SIC) celebrated an artistic triumph: the prestigious Caméra d'Or for Best Debut Feature film was awarded to Keren Yedaya's Or (My Treasure, Israel-France), a biting fiction-documentary set in Tel Aviv about a mother who works as a prostitute and her 17-year-old daughter who works various odd jobs to help put food on the table. The International Critics (FIPRESCI) Jury awarded an Israeli-Palestine entry in the Critics Week: Tawfik Abu Wael's Atash (Thirst), an ardent plea for the cause of the Palestinian people who are forced from their lands to subsist as best they can in the desert. This is Claire Clouzot's final year as head of an ever more enterprising and surprising Critics Week.

The Directors Fortnight under its new programming director, Olivier Père, also enjoyed heavy attendance, thanks in good part to the support given its entries daily by L'Humanité. The section's opening night feature, Katsuhito Ishii's Cha no aji (A Taste of Tea, China), was a hit with both the critics and the audience. A wacky, surrealist fantasy, it's about the eccentricities of a family living in a small mountain town not too far from Tokyo. The key figure is the mother, who decides to come out of retirement to work again in film animation. Four years in the making, the story was pieced together gradually by character sketches. "I just had fun every day," said Katsuhito Ishii. "There was not a single unpleasant moment." Some critics, recognizing a major directorial talent, felt that A Taste of Tea might easily have contended for the Golden Palm.

\section{Discoveries in the Critics' Week}

Ever since Claire Clouzot, the niece of the late, great French director Henri-Georges Clouzot ( Wages of Fear, 1953, Les Diaboliques, 1955), took over the Semaine Internationale de la Critique section at Cannes, the section has been the talk of the festival. Clouzot, who had studied cinema under the equally late, great Pauline Kael at Stanford University, was ripe for the job when she was handed the reins of the Critics Week three years ago. She has penned a biography on William Klein, the American photographer-documentarist based in Paris whom she counts among her close friends. She has written with authority on the novels and films of Catherine Breillat, contending that her oeuvre is anything but pornographic. And her charismatic ways of dealing with young filmmaking talent bore fruit last year when one of the SIC entries, Christoffer Boe's Reconstruction (Denmark), was awarded the festival's prestigious Caméra d'Or for Best Debut Feature.

"Well, isn't that our job - discovering new talent?!" she retorted with a broad smile when informed that the Caméra d'Or had finally returned to the Week of the Critics, the site of the award's inauguration, after a lapse of more than a decade.

That's only half of the SIC story. The other half is the "Discovery of the Year" film that was introduced into the program to boost its renommé with the international press. Beginning in 2001, and helped considerably by members of the Fédération Internationale de la Presse Cinématographique (FIPRESCI) under General 
Secretary Klaus Eder, the SIC selection committee elected to host annually at Cannes a "critics' discovery" that had surfaced at a key festival over the past year. The idea was threefold: (1) to pay tribute to a key film, (2) to beat the drum for a talented director who has earned his or her place in the front ranks of creative filmmaking, and (3) to spotlight a filmland that is presently nurturing style and vision in its national cinematography.

In 2001, the first "Discovery of the Year" citation, a combined SIC-FIPRESCI Award, paid tribute to Christian Petzold's Die innere Sicherheit (The State I Am In), a prior entry at the 2000 Venice festival. Not since Rainer Werner Fassbinder's Die dritte GenerationThe Third Generation, 1979) had a film of this political brilliance come along to shake up German cinema, for The State I Am In was about the RAF, about terrorism, about hiding in the underground - in short, about themes that are generally anathema to TV producers and funding boards. Indeed, in the light of today's events, the film well deserves to be listed among the best European films of the new millennium. (

In 2002, the "Discovery of the Year" award went to Ulrich Seidl's Hundstage (Dog Days, Austria). This time, FIPRESCI could make up for an embarrassing oversight, when, at the 2001 Venice festival, its August members had overlooked the Grand Jury Prize winner on the Lido. An earthy, ribald, multicolored portrait of the lower middle-class by an award-winning documentarist, Dog Days might be considered cruel and tasteless were it not for its open compassion for lonely people who manage to carry on with their quaint fantasies and modest aspirations.

Last year, the SIC "Discovery of the Year" went to Lee Chang-dong's Oasis (South Korea), a love story, though anything but a tale of romance and fantasy. Once again, Oasis found its way to the Riviera from the Lido. The story of an ex-con and a social outcast, the latter a woman with cerebral palsy, the pair confront a cold and indifferent society who view their union as unnatural and criminal. Lee's previous film, Peppermint Candy, had opened the 2000 Pusan film festival, was invited to the Directors Fortnight at Cannes, and competed at Karlovy Vary. Oasis won him the Best Director award at Venice.

This year, the SIC "Discovery of the Year" goes to Boris Chlebnikov and Alexei Popogrebsky's Koktebel (Russia), the title referring to a resort town in the Crimea. A debut feature film about a father and his young son on an arduous journey by foot from Moscow to the Black Sea, the tale enhanced by the odd company they keep along the way, it was awarded the Special Jury Prize and the FIPRESCI Award at Moscow, the Philip Morris Prize at Karlovy Vary, and, recently, Best Film at the GoEast Film Festival of Central and Eastern European Films at Wiesbaden. Indeed, Koktebel is one of a handful of recent productions that heralds a Russian film renaissance.

This may be Claire Clouzot's last year as head of the SIC committee. It's been rumoured she wants to return to writing biographies and making documentary portraits about friends. Forgive the pun: SIC transit gloria mundi. The Semaine will look bleak without her.

\section{Henri Langlois @ Cannes}

Don't miss Jacques Richard's Le fantôme d'Henri Langlois - its catchy English title is Henri Langlois: The Phantom of the Cinematheque - which premiered in the Cannes Classics section, a showcase of restored film classics and documents about the history of the cinema.

Aimed to quell the appetite of an ever growing number of cineastes and festivaliers for restored film classics and documentaries about the history of the cinema, "Cannes Classics" is programmed in the Salle Buñuel under the roof of the Palais des Festivals. The highlight of this section is a three-and-a-half-hour documentary about a man who went from a legend in his lifetime to a myth in the hereafter.

This is the second film Jacques Richard has made on Henri Langlois. The first, Langlois Monumental (1991), made for television, ran only 11 minutes. But it was packed to the brim with pithy statements on Langlois by Marcel Carné, Henri Alekan, Samuel Fuller, and other eminent film personalities.

That insightful portrait, in turn, should not be confused with another French documentary: Roberto Guerra and Elia Hershon's 52-minute Henri Langlois (1970), aka Langlois. That documentary was made as a kind of apologia pro vita sua on Langlois's behalf when he was reinstated as head of the Cinémathèque française. It 
featured interviews by Ingrid Bergman, Catherine Deneuve, Lillian Gish, Jeanne Moreau, Simone Signoret, François Truffaut, and Henri Langlois himself.

Why André Malraux, the then French Minister of Culture, had fired Henri Langlois in 1968 as head of the Cinémathèque Française is today pretty much a mute question. Let's just say that Langlois was one of the wheels in the ' 68 Student Revolt that closed the Sorbonne for nine months and brought the Cannes film festival to a grinding halt midway through its fanfare.

HTML clipboard

Of course, there were other reasons given as well. Henri Langlois was running the August institution he had co-founded (with Georges Franju) like his own private fiefdom. Founded in 1936, from just 10 films out of his own private collection, the renown Cinémathèque Française had grown in 1968 to house some 60,000 prints. Indeed, literally thousands of prints had been saved from destruction. No one knew how many of these were "stolen prints," for Langlois paid no attention whatsoever to copyright laws and accordingly kept no records. That, in essence, was where the trouble began. And it didn't end until 1974, when the Hollywood Studios swallowed their pride and bestowed on Henri Langlois an Honorary Oscar "for his devotion to the art of the film, his massive contribution to preserving the past, and his unwavering faith in the future."

Every one who had rubbed shoulders with Langlois at the Cinémathèque has a story to tell about the legend to enhance the myth. Just ask veteran critics at Positif, Cahiers du Cinéma, and Le Monde. Or listen again to the testimonials rendered at Langlois's death in 1977 by Godard, Truffaut, Chabrol, Demy, and other nouvelle vague directors who learned filmmaking by sitting for hours in the venues of the Cinémathèque Française at the Palais de Chaillot and the Odéon. Pierre Henri Deleau, the programming head of the Quinzaine des Réalisateurs, placed a saintly looking Henri Langlois on the front cover of the 1977 Directors' Fortnight catalogue, accompanied inside by a moving essay in Langlois's honour by poet Pierre Kast.

I first met Henri Langlois in 1965. While attending a film conference at Lincoln Center in conjunction with the New York Film Festival, I had the good fortune to meet Langlois at a reception in the home of Amos Vogel, the co-director of the NYFFF. When I asked if I could spend a summer month assisting him at the Cinémathèque, he had only one reservation: Would I be willing to bring some films with me from New York to Paris?

Thus began my short, but fruitful, career as a film smuggler. And the rewards were inestimable.

During the day, I would shuffle papers and documents for Lotte Eisner in the office of the Cinémathèque. In the evening, I devoured countless film classics at the Odéon with my free pass. I also attended the "Special Events" in the Palais de Chaillot - for instance, the screening of Roberto Rossellini's Le prise de pouvoir par Louis XIV (Louis XIV Rises to Power, 1966), with Rossellini himself present to introduce the film.

I learned too how to watch Ozu films without subtitles in any language. We were simply handed a synopsis at the door, read it through before the screening, and then paid close attention to the framing of the image to catch nuances in a film that subtitling would perforce distract one from seeing at all.

One evening, after a Chaillot program, Henri Langlois asked if I would care to watch with him a half-dozen silent Mary Pickford films from her own private collection that had just arrived in Paris. From midnight until four in the morning, I looked at the most stunning nitrate images I had ever seen. Langlois asked his projectionist to screen different roles from different productions to check the condition of each print and compare the overall quality of the program.

Some rows before me sat Mary Meerson (the wife of the late Lazare Meerson, art director on René Clair films). Around three in the morning we could hear her peacefully snoring away. Later, Langlois invited me to breakfast with him at a restaurant near Les Halles to talk about his retrospective tributes to Blanche Sweet and Lillian Gish at the Cinémathèque.

Some years later, while attending the Istanbul film festival, I had lunch with Şakir Eczacibaşi, the festival patron up to the present day. He told me how his friendship with Henri Langlois - born in Izmir, Turkey, in 1914 - had begun on a visit to Paris. One day, Langlois asked Eczacibaşi for the name of a promising new 
director in Turkish in the retrospective of New Turkish Cinema he was about to program at the Cinémathèque. He needed a "discovery" to kick off a planned retro.

The next day, without batting an eyelash, Henri Langlois announced to the French press the name of a "great new Turkish director" - Yilmaz Güney - whose film in the program he himself had yet to see.

But Langlois, in his usual slipshod way of doing things, had hit the nail right on the head again. Years later, while Yilmaz Güney was serving a prison sentence on an island in the Mediterranean for killing a man, he scripted and storyboarded a film to be co-directed by actor Serif Gören. Yol was awarded the Golden Palm in 1982 - over loud protests from the Turkish government.

Even from the hereafter, Henri Langlois still had his hand on the greatest film festival on earth.

\section{References}

AWARDS

OFFICIAL COMPETITION

Palme d'Or: Fahrenheit 9/11 (USA), Michael Moore

Grand Prix: Old Boy (South Korea), Park Chan-wook

Best Director: Tony Gatlif, Exils (Exiles, France)

Best Screenplay: Agnès Jaoui and Jean-Pierre Bacri, Comme une image (Look At Me, France)

Best Actress: Maggie Cheung, Clean (France-UK-Canada), Olivier Assayas

Best Actor: Yagira Yuuya, Daremo shiranai (Nobody Knows, Japan), Kore-Eda Hirokazu

Jury Prize: (ex aequo) Irma P. Hall, The Ladykillers (USA), Joel and Ethan Coen, and Sud pralad (Tropical Malady), Thailand), Apichatpong Weerasethakul

\section{Short Film Awards}

Palme d'Or: Traffic (Romania), Catalin Mitulescu

Jury Prize: Flatlife (Belgium), Jonas Geimhart

Caméra d'Or (Best Debut Feature): Or (My Treasure) (Israel-France), Keren Yedaya (Critics Week)

Special Mentions: Lu cheng (Passages, China), Yang Chao (Un Certain Regard); Khab é talkh (Bitter Dream, Iran), Mohsen Amiryoussefi (Directors Fortnight)

\section{Cinéfondation Awards}

First Prize: Happy Now (Denmark), Frederrike Aspøch

Second Prize: (ex aequo) Calatorie la oras (A Trip to the City), Romania), Corneliu Porumboiu, 99 vu otta Elämästani (99 Years of My Life, Finland), Marja Mikkonen

Third Prize: Fajnie, je jestes (Nice to See You, Poland), Jan Komasa

\section{OTHER AWARDS}

Festival Trophies Max von Sydow and Gong Li

Prix Vulcain (Technical Award) Cameraman Eric Gautier, DP: Diarios de motocicleta (The Motorcycle Diaries, Brazil-Argentina-USA), Walter Salles (Competition); Clean (France-UK-Canada), Olivier Assayas (Competition)

François Chalais Prize Diarios de motocicleta (The Motorcycle Diaries, Brazil-Argentina-USA), Walter Salles (Competition)

Special Mention Machuca (Chile-Spain-France), Andrés Wood (Directors Fortnight) 
National Education Prize Život je čudo (Life Is a Miracle, Serbia-Montenegro), Emir Kusturica (Competition)

International Critics (FIPRESCI) Awards:

Competition: Fahrenheit 9/11 (USA), Michael Moore

Un Certain Regard: Whisky (Uruguay), Juan Pablo Rebella, Pablo Stoll

Critics Week: Atash (Thirst, Israel-Palestine), Tawfik Abu Wae

Ecumenical Award Diarios de motocicleta (The Motorcycle Diaries, Brazil-Argentina-USA), Walter Salles

Special Mention Moolaadé (Senegal-France), Ousmane Sembène

UN CERTAIN REGARD AWARDS

Prix Un Certain Regard: Moolaadé (Senegal-France), Ousmane Sembène

Prix du Regard Original Whisky (Uruguay), Juan Pablo Rebella, Pablo Stoll

Prix du Regard vers l'Avenir Khakestar-o-khak (Earth and Ashes, Afghanistan-France), Atiq Rahimi

Prix du Regard Jeune (Youth Prize) Kontroll (Control, Hungary), Nimrod Antal

DIRECTORS FORTNIGHT AWARDS

CICAE Arthouse Prize The Woodsman (USA), Nicole Kassell (Directors Fortnight)

Carosse d'Or (Awarded by Film Directors Society) Nanni Moretti

CRITICS WEEK AWARDS

Grand Prix: (ex aequo) Brodeuses (A Common Thread, France), Éléonore Faucher, Or (My Treasure) (Israel-France), Keren Yedaya

Prix SACD (Screenwriters Prize, ex aequo): Éléonore Faucher and Gaëlle Macé, Brodeuses (A Common Thread, France), Keren Yedaya and Sari Ezouz, Or (My Treasure), (Israel-France)

Prix Canal+ (Best Short Film): Ryan (Canada), Chris Landreth

Prix Découverte Kodak (Short Film): Ryan (Canada), Chris Landreth

Prix de la Jeune Critique:

Feature Film: Or (My Treasure, Israel-France), Keren Yedaya

Short Film: Ryan (Canada), Chris Landreth

Prix Regards Jeunes

Feature Film: Or (My Treasure, Israel-France), Keren Yedaya

Short Film: L'homme sans ombre (The Man Without a Shadow, Canada-Switzerland), Georges Schwizgebel

Grand Rail d'Or: CQ2 (Seek You Too, Canada-France), Carole Laure

Petit Rail d'Or: Alice et moi (Alice and Me, Belgium), Micha Wald

\section{Author Information}

Ron HOLLOWAY (1933-2009) was an American critic, film historian, filmmaker and correspondent who adopted Europe as his home in the early fifties and spent much of his life in Berlin. He was an expert on the study of German cinema and against all odds produced, with his wife Dorothea, the journal German Film, keeping us up-to-date with the work of directors, producers and writers and the showing of German films around the world. 
In 2007, Ron Holloway and his wife were awarded the Berlinale Camera Award. Ron also received the Bundesverdienstkreuz (German Cross of Merit), Polish Rings, Cannes Gold Medaille, the American Cinema Foundation Award, the Diploma for Support of Russian Cinema and an honorary award from the German Film Critics' Association.

Ron was also a valued contributor to Kinema for the past fifteen years. 